\title{
Original
}

\section{Monomer release from nanohybrid composites after bleaching}

\author{
Pinar Gul1), Ozcan Karatas'), Hamit H. Alp2), Ihsan B. Cam³), \\ and Nurcan Ozakar-Ildayl)
1)Department of Restorative Dentistry, Faculty of Dentistry, Atatürk University, Erzurum, Turkey
2)Department of Biochemistry, Faculty of Medicine, Yüzüncü Yıl University, Van, Turkey
3)Akdeniz University, Food Safety and Agricultural Research Center, Antalya, Turkey

(Received February 27, 2018; Accepted October 26, 2018)

\begin{abstract}
The evaluation of the effect of bleaching on monomer release from two composite resins was performed by bleaching two nanohybrid composite resins Filtek Z550 and Tetric N-Ceram using two bleaching products Whiteness HP Maxx and Vivastyle. In total, 20 samples were made from each composite resin from which four groups were fabricated (two for each bleaching product). The samples were stored in a $75 \%$ ethanol solution, and the solutions were renewed after 1, 7, and 28 days. The monomer release was analyzed using high performance liquid chromatography. The data were analyzed using repeated measures analysis of variance and least significant difference multiple comparison test $(\alpha=0.05)$. Monomers were found to be released from both composite resins. The amounts of monomer released were found to decrease over time $(P<0.05)$; however, the resins were not affected by bleaching, and the released monomers were well below toxic doses.
\end{abstract}

Keywords: nanohybrid composite resins; home-type bleaching; monomer release; office-type bleaching.

Correspondence to Dr. Pinar Gul, Department of Restorative Dentistry, Faculty of Dentistry, Atatürk University, Yakutiye, Erzurum, TR-25240, Turkey

Fax: +90-442-236-0945 E-mail: opinargul@gmail.com

Color figures can be viewed in the online issue at J-STAGE.

doi.org/10.2334/josnusd.18-0063

DN/JST.JSTAGE/josnusd/18-0063

\section{Introduction}

Composite resins are among the most commonly used materials in dentistry for direct filling and as an adhesive agent for inlays, crowns, orthodontic brackets, and veneers (1). Composite resins consist primarily of bisphenol A glycerolate dimethacrylate (BISGMA), urethane dimethacrylate (UDMA), and triethylene glycol dimethacrylate (TEGDMA) methacrylic monomers. The presence of additives, such as initiators, activators, inhibitors, and plasticizers, is also required for restorative materials (2). Bisphenol A (BPA) is also found in fissure sealant materials, which are in contact with composite resins (3).

More recently, nanohybrid composite resins have been introduced, containing a range of different sizes of macrofillers and microfillers, to which some nanoscalesized fillers have been added. The nanoscale-sized fillers occupy the spaces between larger particles and may lead to shorter particle spacing. Nanoscale-sized fillers (1-100 $\mathrm{nm}$ ) are smaller than the wavelength of light and have been used as composites to provide a combination of the good mechanical properties of macrofilled composites and the excellent optical qualities of microfilled composites (4). Consequently, modern nanohybrid composite resins are used as universal restorative dental materials with a wide range of applications.

Dental bleaching treatment is widely applied in modern dentistry to meet people's increased esthetic expectations. Bleaching agents, containing hydrogen peroxide (HP) and carbamide peroxide (CP), are used in various forms and concentrations by patients and clinicians $(5,6)$. 
Table 1 Details of the investigated materials

\begin{tabular}{|c|c|c|c|}
\hline Materials & Type & Content & Manufacturer \\
\hline Filtek Z550 & Nanohybrid & $\begin{array}{l}\text { BISGMA, UDMA, PEGDMA, and TEGDMA } \\
\text { Surface modified zirconia and silica fillers ( } 3 \mu \mathrm{m}) \text {, } \\
68 \% \text { volume, } 82 \% \text { weight }\end{array}$ & $\begin{array}{l}\text { 3M ESPE, St. Paul, } \\
\text { MN, USA }\end{array}$ \\
\hline Tetric N-Ceram & Nanohybrid & $\begin{array}{l}19 \%-20 \% \text { BISGMA, UDMA } \\
\text { Barium glass, } \mathrm{YbF}_{3}(0.04-3 \mathrm{~mm}), 55-57 \% \text { volume, } \\
80 \% \text { weight }\end{array}$ & $\begin{array}{l}\text { Ivoclar Vivadent, } \\
\text { Schaan, Liechtenstein }\end{array}$ \\
\hline $\begin{array}{l}35 \% \text { Whiteness HP } \\
\text { Maxx }\end{array}$ & $\begin{array}{l}\text { Chemically activated office-type } \\
\text { bleaching agent }\end{array}$ & $35 \% \mathrm{H}_{2} \mathrm{O}_{2}$ & FGM, Joinville, SC, Brazil \\
\hline $16 \%$ Vivastyle & $\begin{array}{l}\text { Chemically activated home-type } \\
\text { bleaching agent }\end{array}$ & $16 \% \mathrm{CH}_{4} \mathrm{~N}_{2} \mathrm{O} \cdot \mathrm{H}_{2} \mathrm{O}_{2}$ & Ivoclar Vivadent \\
\hline
\end{tabular}

Table 2 Details of the investigated monomers

\begin{tabular}{llccc}
\hline Monomers & \multicolumn{1}{c}{ Name } & Chemical formula & Molecular weight & CAS number \\
\hline BPA & bisphenol A & $\mathrm{C}_{15} \mathrm{H}_{16} \mathrm{O}_{2}$ & 228.29 & $80-05-7$ \\
HEMA & 2-hydroxyethyl methacrylate & $\mathrm{C}_{6} \mathrm{H}_{10} \mathrm{O}_{3}$ & 130.14 & $868-77-9$ \\
TEGDMA & triethylene glycol dimethacrylate & $\mathrm{C}_{14} \mathrm{H}_{22} \mathrm{O}_{6}$ & 286.32 & $109-16-0$ \\
UDMA & urethane dimethacrylate & $\mathrm{C}_{23} \mathrm{H}_{38} \mathrm{~N}_{2} \mathrm{O}_{8}$ & 470.56 & $41137-60-4$ \\
BISGMA & bisphenol A glycerolate dimethacrylate & $\mathrm{C}_{29} \mathrm{H}_{36} \mathrm{O}_{8}$ & 513.00 & $1565-94-2$ \\
\hline
\end{tabular}

$\mathrm{CP}$ is used in home-type bleaching in concentrations of $6.5-22 \%$, whereas HP is used by dentists in office-type bleaching in concentrations of $25-35 \%$ (7). When CP combines with saliva during bleaching, it converts into HP and urea, and HP reacts to form oxygen and water (8). In both bleaching methods, especially in office-type bleaching, tooth sensitivity and pulp damage may occur due to HP (9).

Composite resins are considered to be very stable in structure; however, the resins cannot be fully polymerized intraorally, and residual monomer may be released into the saliva (10). Monomer release from composite resins has been evaluated in many studies; however, very little data is available on the effect of bleaching on monomer release $(11,12)$.

Monomer release from resin-based composites reduces the biocompatibility of these materials. In vitro studies have shown that BISGMA, TEGDMA, UDMA, and 2-hydroxyethyl methacrylate (HEMA) monomers have cytotoxic and genotoxic effects on certain cell types $(13,14)$. Methacrylate monomers have a negative effect on cell homeostasis even at low concentrations (15).

Knowing the mechanism and determining the type and amount of monomers released is important for understanding the degradation process of polymerbased materials and for taking precautions in clinical applications. For this purpose, the amount of monomer released from two nanohybrid composite resins upon which two different bleaching processes were applied were measured and the effect of the bleaching process on monomer release was determined.

The hypothesis of this study was that bleaching processes do not affect the monomers released from nanohybrid composite resins.

\section{Materials and Methods}

Two vital bleaching products 35\% Whiteness HP Maxx (FGM, Joinville, SC, Brazil) and 16\% Vivastyle (Ivoclar Vivadent, Schaan, Liechtenstein) and two commercial nanohybrid composite resins Filtek Z550 (3M ESPE, St. Paul, MN, USA) and Tetric N-Ceram (Ivoclar Vivadent, Schaan, Liechtenstein) were tested. Tables 1 and 2 provide information regarding the materials.

\section{Preparation of samples}

In total, 20 samples were prepared from each composite resin using a 5-mm diameter and 2-mm depth stainless steel mold. The molds were filled with composite resin, and the upper and lower surfaces were compressed between two glass surfaces to obtain a smooth surface while using a mylar strip for oxygen inhibition. A lightemitting diode (Elipar Freelight II, 3M ESPE) was used to perform polymerization. The light intensity of the polymerization device $\left(1,200 \mathrm{~mW} / \mathrm{cm}^{2}\right)$ was measured with a radiometer (Hilux Ultra Plus Curing Units, Benlioglu Dental, Ankara, Turkey). Prior to bleaching, 

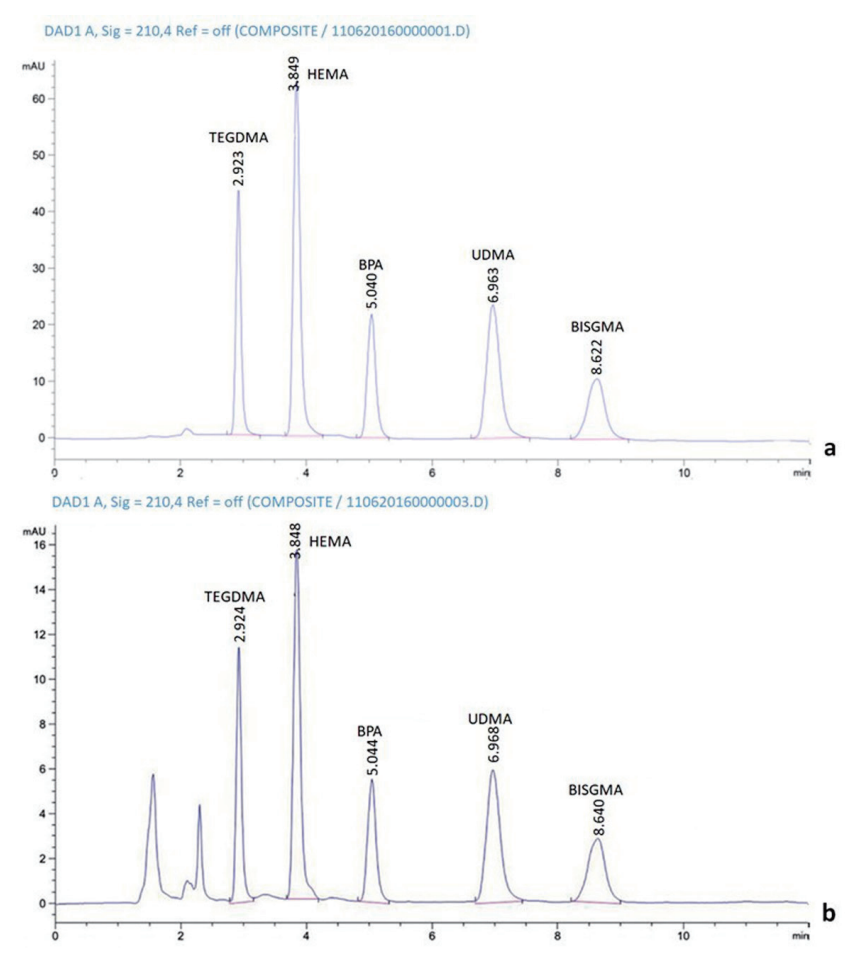

Fig. 1 a, chromatogram of the standard monomers. b, chromatogram of the monomers released from one of the samples.

the samples were stored in an artificial saliva preparation at room temperature for $72 \mathrm{~h}$. Artificial saliva was prepared by the Department of Biochemistry, Faculty of Medicine, Atatürk University. The artificial saliva contained $4.1 \mathrm{mM}$ potassium dihydrogen phosphate, 4.0 $\mathrm{mM}$ disodium hydrogen phosphate, $24.8 \mathrm{mM}$ potassium bicarbonate, $16.5 \mathrm{mM}$ sodium chloride, $0.25 \mathrm{mM}$ magnesium chloride, $4.1 \mathrm{mM}$ citric acid, and $2.5 \mathrm{mM}$ calcium chloride (16).

The samples of both prepared composites were divided into four groups with five samples in each group. Half of the composite samples were bleached with one of the two bleaching products (office group and home group), and the other two groups were used as controls (office control group and home control group). The HP-containing office-type bleaching process was applied for $45 \mathrm{~min}$ (equivalent to three applications for $15 \mathrm{~min}$ ). The CP-containing home-type bleaching agent was applied for $14 \mathrm{~h}$ ( $1 \mathrm{~h}$ per day for 14 days). After bleaching, each sample was stored in $1 \mathrm{~mL}$ of $75 \%$ ethanol solution at room temperature for 28 days. The solutions were renewed after 1 and 7 days. The solutions obtained were stored at $4^{\circ} \mathrm{C}$ until analysis.

\section{High performance liquid chromatography (HPLC) analysis}

The monomer analysis of the samples was performed using HPLC (Agilent 1200 series, isocratic pump,

auto sampler, column frame, and diode array detector, $\mathrm{GmbH}$, Boeblingen, Germany) with a $\mathrm{C} 18$ reverse-phase analytical column $(250 \times 4.6 \mathrm{~mm}, 5 \mu \mathrm{m}$ particle size, ACE, Aberdeen, Scotland). High purity standard testing solutions were purchased from Sigma-Aldrich.

The analysis of the samples was performed by modifying the method of Pelka et al. (17). Acetonitrile/ water in the ratio of $65 \% / 35 \%$ was used as the mobile phase. Flow rate and run time were set to $1 \mathrm{~mL} / \mathrm{min}$ and 12 min. Standard BPA, TEGDMA, BISGMA, UDMA, and HEMA monomers were injected into the device at appropriate rates to create standard HPLC spectra. The retention times and peak values of these monomers were recorded, and the monomer concentrations were determined in $\mu \mathrm{mol} / \mathrm{L}$ based on calculation of the area under the peaks obtained from the standard solutions.

\section{Statistical analysis}

Statistical Package for the Social Sciences (SPSS) 18 (IBM, Chicago, IL, USA) statistical package software was used to analyze the data. Kolmogorov-Smirnov and Shapiro-Wilk tests were used to determine the distribution of the data. Additionally, data normality verification (equality of variances) was performed using Levene's test. Nonparametric tests were performed because the variances of some groups were not homogeneous. Friedman's test was used to determine whether a significant difference existed between time periods in terms of the amount of monomers released from the composite resins. When differences were detected, the Wilcoxon signed-rank test was used to determine the source of the difference.

Additionally, the Kruskal-Wallis test was used to compare the bleaching groups, and the Mann-Whitney $U$ test was used to compare the composite resins. $P<0.05$ was considered statistically significant.

\section{Results}

Figures 1a and $\mathrm{b}$ show the standards and the chromatograms of one of the studied samples. The retention times of monomers detected for TEGDMA, HEMA, BPA, UDMA, and BISGMA were 2.9, 3.8, 5.0, 6.9, and 8.6 min, respectively.

Monomer was released at all times from all composite samples. Tables 3 and 4 show the monomer types and the amounts released after application of the two bleaching products to the composite resins and the results of the statistical comparison. The amounts of monomer released from the two nanohybrid composite resins decreased over time $(P<0.05)$. HEMA was released the most, whereas TEGDMA was released the least. 
Table 3 Released monomers from composite resins after bleaching with 35\% Whiteness HP Maxx

\begin{tabular}{|c|c|c|c|c|c|}
\hline & Composite resins & Bleaching application & $\begin{array}{c}1 \text { day } \\
\text { mean }(\mathrm{SD})\end{array}$ & $\begin{array}{c}7 \text { days } \\
\text { mean }(\mathrm{SD})\end{array}$ & $\begin{array}{c}28 \text { days } \\
\text { mean }(\mathrm{SD})\end{array}$ \\
\hline \multirow[t]{4}{*}{ BPA } & FZ550 & Yes & $0.27(0.10) \mathrm{a}$ & $0.45(0.30) \mathrm{a}$ & $0.45(0.30) \mathrm{a}$ \\
\hline & & No & $0.24(0.17) \mathrm{a}$ & $0.30(0.12) \mathrm{a}$ & $0.23(0.07) \mathrm{a}$ \\
\hline & $\mathrm{TNC}$ & Yes & $0.32(0.19) \mathrm{a}$ & $0.32(0.07) \mathrm{a}$ & $0.67(0.10) \mathrm{a}$ \\
\hline & & No & $0.43(0.31) \mathrm{a}$ & $0.32(0.23) \mathrm{a}$ & $0.47(0.09) \mathrm{a}$ \\
\hline \multirow[t]{4}{*}{ HEMA } & FZ550 & Yes & $1.80(0.47) \mathrm{a}$ & $2.26(0.83) \mathrm{a}$ & $2.75(0.74) \mathrm{a}$ \\
\hline & & No & $2.01(0.61) \mathrm{a}$ & $2.28(0.71) \mathrm{a}$ & $2.68(0.64) \mathrm{a}$ \\
\hline & $\mathrm{TNC}$ & Yes & $2.52(1.52) \mathrm{a}$ & $1.88(0.36) \mathrm{a}$ & $1.68(1.03) \mathrm{a}$ \\
\hline & & No & $1.95(0.48) \mathrm{a}$ & $1.88(0.22) \mathrm{a}$ & $2.39(0.85) \mathrm{a}$ \\
\hline \multirow[t]{4}{*}{ TEGDMA } & FZ550 & Yes & $0.04(0.03) \mathrm{a}$ & $0.01(0.00) \mathrm{b}$ & $0.02(0.01) \mathrm{a}$ \\
\hline & & No & $0.04(0.02) \mathrm{a}$ & $0.01(0.00) \mathrm{b}$ & $0.01(0.00) \mathrm{b}$ \\
\hline & $\mathrm{TNC}$ & Yes & $0.03(0.01) \mathrm{a}$ & $0.04(0.01) \mathrm{b}$ & $0.01(0.00) \mathrm{a}$ \\
\hline & & No & $0.02(0.01) \mathrm{a}$ & $0.03(0.01) \mathrm{a}$ & $0.02(0.01) \mathrm{a}$ \\
\hline \multirow[t]{4}{*}{ UDMA } & FZ550 & Yes & $0.43(0.10) \mathrm{a}$ & $0.52(0.12) \mathrm{a}$ & $0.19(0.05) \mathrm{b}$ \\
\hline & & No & $0.45(0.12) \mathrm{a}$ & $0.51(0.13) \mathrm{a}$ & $0.19(0.07) \mathrm{b}$ \\
\hline & $\mathrm{TNC}$ & Yes & $0.63(0.16) \mathrm{a}$ & $0.38(0.09) \mathrm{a}$ & $0.59(0.32) \mathrm{a}$ \\
\hline & & No & $0.47(0.09) \mathrm{a}$ & $0.41(0.08) \mathrm{a}$ & $0.57(0.26) \mathrm{a}$ \\
\hline \multirow[t]{4}{*}{ BISGMA } & FZ550 & Yes & $0.63(0.15) \mathrm{a}$ & $0.71(0.12) \mathrm{a}$ & $0.56(0.21) \mathrm{a}$ \\
\hline & & No & $0.59(0.05) \mathrm{a}$ & $0.59(0.12) \mathrm{a}$ & $0.53(0.15) \mathrm{a}$ \\
\hline & $\mathrm{TNC}$ & Yes & $0.54(0.11) \mathrm{a}$ & $0.61(0.13) \mathrm{a}$ & $0.67(0.14) \mathrm{a}$ \\
\hline & & No & $0.50(0.05) \mathrm{a}$ & $0.66(0.15) \mathrm{a}$ & $0.49(0.28) \mathrm{a}$ \\
\hline
\end{tabular}

BPA: bisphenol A; HEMA: 2-hydroxyethyl methacrylate; TEGDMA: triethylene glycol dimethacrylate; UDMA: urethane dimethacrylate; BISGMA: bisphenol A glycerolate dimethacrylate; FZ550: Filtek Z550; TNC: Tetric N-Ceram; SD: standard deviation. Different lowercase letters indicate a significant difference in the same row.

Table 4 Released monomers from composite resins after bleaching with 16\% Vivastyle

\begin{tabular}{|c|c|c|c|c|c|}
\hline & Composite resins & Bleaching application & $\begin{array}{c}1 \text { day } \\
\text { mean }(\mathrm{SD})\end{array}$ & $\begin{array}{c}7 \text { days } \\
\text { mean }(\mathrm{SD})\end{array}$ & $\begin{array}{c}28 \text { days } \\
\text { mean }(\mathrm{SD})\end{array}$ \\
\hline \multirow[t]{4}{*}{ BPA } & FZ550 & Yes & $0.25(0.12) \mathrm{a}$ & $0.55(0.37) \mathrm{a}$ & $0.34(0.15) \mathrm{a}$ \\
\hline & & No & $0.23(0.08) \mathrm{a}$ & $0.38(0.22) \mathrm{a}$ & $0.52(0.11) \mathrm{a}$ \\
\hline & $\mathrm{TNC}$ & Yes & $0.36(0.21) \mathrm{a}$ & $0.36(0.27) \mathrm{a}$ & $0.54(0.07) \mathrm{a}$ \\
\hline & & No & $0.38(0.18) a$ & $0.61(0.51) \mathrm{a}$ & $0.56(0.10) \mathrm{a}$ \\
\hline \multirow[t]{4}{*}{ HEMA } & FZ550 & Yes & $2.65(0.75) \mathrm{a}$ & $3.26(0.75) \mathrm{a}$ & $2.68(0.55) \mathrm{a}$ \\
\hline & & No & $2.16(0.63) \mathrm{a}$ & $3.11(0.52) \mathrm{a}$ & $2.50(0.46) \mathrm{a}$ \\
\hline & $\mathrm{TNC}$ & Yes & $1.93(0.56) \mathrm{a}$ & $2.03(0.47) \mathrm{a}$ & $1.91(0.64) \mathrm{a}$ \\
\hline & & No & $1.75(0.27) \mathrm{a}$ & $3.04(0.67) b$ & $1.86(0.88) \mathrm{a}$ \\
\hline \multirow[t]{4}{*}{ TEGDMA } & FZ550 & Yes & $0.04(0.01) \mathrm{a}$ & $0.01(0.00) b$ & $0.02(0.01) b$ \\
\hline & & No & $0.05(0.03) \mathrm{a}$ & $0.02(0.01) \mathrm{a}$ & $0.03(0.02) \mathrm{a}$ \\
\hline & $\mathrm{TNC}$ & Yes & $0.02(0.01) \mathrm{a}$ & $0.03(0.02) \mathrm{a}$ & $0.04(0.01) \mathrm{a}$ \\
\hline & & No & $0.03(0.01) \mathrm{a}$ & $0.01(0.00) \mathrm{b}$ & $0.05(0.01) \mathrm{c}$ \\
\hline \multirow[t]{3}{*}{ UDMA } & FZ550 & Yes & $0.41(0.12) \mathrm{a}$ & $0.67(0.11) b$ & $0.29(0.05) \mathrm{c}$ \\
\hline & TNC & Yes & $0.39(0.16) \mathrm{a}$ & $0.63(0.31) \mathrm{a}$ & $0.56(0.04) \mathrm{a}$ \\
\hline & & No & $0.48(0.13) \mathrm{a}$ & $0.26(0.10) a$ & $0.46(0.16) \mathrm{a}$ \\
\hline \multirow[t]{4}{*}{ BISGMA } & FZ550 & Yes & $0.58(0.12) a$ & $0.65(0.06) \mathrm{a}$ & $0.53(0.11) \mathrm{a}$ \\
\hline & & No & $0.61(0.06) \mathrm{a}$ & $0.58(0.11) a$ & $0.81(0.23) \mathrm{a}$ \\
\hline & $\mathrm{TNC}$ & Yes & $0.63(0.11) a$ & $0.51(0.19) \mathrm{a}$ & $0.98(0.37) b$ \\
\hline & & No & $0.70(0.08) \mathrm{a}$ & $0.79(0.19) \mathrm{a}$ & $0.64(0.16) \mathrm{a}$ \\
\hline
\end{tabular}

The amounts of BPA, HEMA, and BISGMA released from either composite resin in the office-type bleaching groups were not statistically significant at any time period $(P>0.05)$. In the home-type bleaching groups, the differences were significant except for BPA (Tables $3,4, P>0.05)$.

No significant differences were detected between the two bleaching systems. No statistically significant differences in the amounts of monomer released $(P>0.05)$ were found between the nanohybrid composite resins.

\section{Discussion}

The biocompatibility of materials used in dentistry is always an important consideration. Ideally, the material 
used in the mouth of the patient should be neither toxic nor estrogenic. It should not cause allergic reactions or have any harmful effects on the pulp. Bleaching is considered to be a reliable and conservative approach that fulfills these criteria. However, various studies have shown that bleaching agents may cause filler loss by causing water absorption in the resin-containing filler composite materials, leading to roughening and a decrease in surface hardness $(18,19)$. Bleaching processes affect the surface properties and hardness of composite materials; therefore, it is important to identify and measure the monomers released from a restorative material. The effect of bleaching agents on restoration and tooth surface properties, hardness, and restorative material's color and marginal integrity have been studied $(20,21)$. Bleaching systems that affect restorative materials will likely affect monomer release.

The HPLC technique is the most suitable method for eluting the non-polar compounds that form the composite resin's monomer, with its advantage of separating the components according to the hydrophobicity (22). Because the monomers can be dissolved in the mobile phase while using the HPLC method, the separation process is performed in a controlled manner. High molecular weight monomers, such as BISGMA and UDMA, may decompose during the gas chromatography (GC) technique, with only decomposition products being detected. This makes GC inferior to the HPLC method used in this study (23).

Silane bonding agents, such as 3-methacryloxypropyltrimethoxysilane, are commonly used in dentistry to chemically bond the organic and inorganic structures. The released material after bleaching composite resins was examined in a study by Durner et al. (7); the detection of diethoxydimethylsilane in the solution was noted to be a sign that the bleaching agent increased monomer release from recently cured composites. Monomer released from bleached dental composite restorations was examined by Polydorou et al. (8) with the observation that bleaching increased the monomer release. The amount of monomer released from composite resins treated with CP-containing bleaching agents at concentrations of $15 \%$ and $35 \%$ was measured by Schuster et al. (9) with the finding that bleaching could either increase or decrease monomer release. Further, $\mathrm{CP} / \mathrm{HP}$ in the bleaching gel was found to damage the polymer network, leading to the increased monomer release. Long-chain molecules, such as TEGDMA and BISGMA, may undergo oxidative decomposition due to peroxides that can decrease monomer release.

The results of the current study are similar to those of Polydorou et al. (24) wherein bleaching two resin composites (a nanohybrid and an ormocer) did not increase the amount of monomer released. In this study, bleaching was observed to not have a significant effect on the amounts of monomer released from either nanohybrid composite resin, and no significant difference was measured between bleaching systems. There was no statistically significant difference in the amounts of monomer released between the nanohybrid composite resins $(P>0.05)$. The similar amounts released from the two composite resins can be explained by the similar filler and matrix content. The similar monomer release caused by either of the bleaching products may be attributed to the high concentration of HP in one, and a longer application time in the other. One limitation of this study is the examination of only nanohybrid composite resins. Further studies for other composite resins and bleaching agents are needed to verify these findings.

Although significant improvements have been made in composite resins, residual monomer release has not been eliminated. Toxic effects of the released monomers have been investigated, and the studies have shown that these monomers have a negative effect on human health. Residual monomers are cytotoxic and may cause allergic reactions, bacterial growth, and soft tissue irritation $(21,25,26)$. Cell cultures have shown that the monomers released from the resin-based materials affect the redox balance in cells by forming reactive oxygen species (ROS) (15). In a study by Demirci et al. (27), $1.5 \mathrm{mmol} / \mathrm{L}$ TEGDMA was observed to triple the level of ROS in normal pulp cells. TEGDMA and HEMA was reported to suppress heat shock protein 72 (HSP 72) in human monocytes by Noda et al. (28), and TEGDMA was observed to cause mitochondrial damage by Lefeuvre et al. (29). HSPs are secreted by cells when stimulated by stress factors, such as temperature, chemicals, and bacteria (30). All released monomers were observed to cause a decrease in mitochondrial activity by Issa et al. (31). Furthermore, the toxicity of BISGMA was observed to be greater than that of TEGDMA, and the least toxic monomer was found to be HEMA (31). $\mathrm{H}_{2} \mathrm{O}_{2}$ was found to increase the toxicity of TEGDMA and UDMA but not that of HEMA and BISGMA by Reichl et al. (32). The fact that composite resins containing TEGDMA produced toxic effects in oral mucosal cells was emphasized by Moharamzadeh et al. (33), with the toxicity order identified as BISGMA > TEGDMA > UDMA.

The key factors that lead to apoptosis in cells include ROS production, delay in cell cycle, suppression of cell division, and consumption of intracellular glutathione. HEMA, TEGDMA, and UDMA cause glutathione 
depletion in human fibroblasts during early periods of growth (34). The degree of glutathione depletion was found to depend on the type of resin monomer (UDMA $>$ TEGDMA > HEMA) by Volk et al. (34). In another study by Volk et al. (35), the glutathione consumption caused by TEGDMA in human gingival fibroblasts was found to be increased in the presence of $\mathrm{H}_{2} \mathrm{O}_{2}$. TEGDMA was observed to decrease glutathione levels to $0.5-5 \mathrm{mM}$ but not increase ROS levels by Engelmann et al. (36). Further, compared to TEGDMA, BISGMA was observed to cause a much faster and more intense reduction of human gingival fibroblasts at much lower concentrations by Engelmann et al. (37).

Studies regarding BPA have focused on hormone-like activity (38). BPA concentrations $>0.01 \mathrm{mmol} / \mathrm{L}$ was noted to have an estrogen-like effect by Kita et al. (39). Studies regarding cytotoxic doses of other monomers released from composite resins have shown that the toxic doses of UDMA, BISGMA, and TEGDMA on human oral mucosa membrane cells were $0.27 \mathrm{mmol} / \mathrm{L}, 0.11$ $\mathrm{mmol} / \mathrm{L}$, and $3.7 \mathrm{mmol} / \mathrm{L}$, respectively (32). Toxic dose of HEMA was found to be $3 \mathrm{mmol} / \mathrm{L}$ for human gingival fibroblasts (40) and $10 \mathrm{mmol} / \mathrm{L}$ for human pulp fibroblast cells (41). The results obtained in the current study are in the $\mu \mathrm{mol} / \mathrm{L}$ range, which is 1,000 times lower than toxic doses stated by other studies $(32,40)$.

The cytotoxic effects of composite materials have not been completely explored yet, particularly with respect to bleaching. Therefore, further in vivo studies would be of interest for nanohybrids.

\section{Acknowledgment}

This work was supported by the Scientific and Technological Research Council of Turkey (TUBITAK) (Project number: 114S911).

\section{Conflict of interest}

The authors have no potential conflict of interest to declare with respect to the authorship and/or publication of this article.

\section{References}

1. Ruyter IE, Sjovik IJ (1981) Composition of dental resin and composite-materials. Acta Odontol Scand 39, 133-146.

2. Rogalewicz R, Batko K, Voelkel A (2006) Identification of organic extractables from commercial resin-modified glassionomers using HPLC-MS. J Environ Monitor 8, 750-758.

3. Olea N, Pulgar R, Perez P, OleaSerrano F, Rivas A, NovilloFertrell A et al. (1996) Estrogenicity of resin-based composites and sealants used in dentistry. Environ Health Persp 104, 298-305.

4. Mitra SB, Wu D, Holmes BN (2003) An application of nano- technology in advanced dental materials. J Am Dent Assoc 134, 1382-1390.

5. Haywood VB (1992) History, safety, and effectiveness of current bleaching techniques and applications of the nightguard vital bleaching technique. Quintessence Int 23, 471-488.

6. Tredwin CJ, Naik S, Lewis NJ, Scully C (2006) Hydrogen peroxide tooth-whitening (bleaching) products: review of adverse effects and safety issues. Brit Dent J 200, 371-376.

7. Durner J, Obermaier J, Ilie N (2014) Investigation of different bleaching conditions on the amount of elutable substances from nano-hybrid composites. Dent Mater 30, 192-199.

8. Polydorou O, Hellwig E, Auschill TM (2006) The effect of different bleaching agents on the surface texture of restorative materials. Oper Dent 31, 473-480.

9. Schuster L, Reichl FX, Rothmund L, He XL, Yang Y, Van Landuyt KL et al. (2016) Effect of Opalescence(R) bleaching gels on the elution of bulk-fill composite components. Dent Mater 32, 127-135.

10. Tabatabaee MH, Arami S, Ghavam M, Rezaii A (2014) Monomer release from nanofilled and microhybrid dental composites after bleaching. J Dent (Tehran) 11, 56-66.

11. Polydorou O, Trittler R, Hellwig E, Kummerer K (2007) Elution of monomers from two conventional dental composite materials. Dent Mater 23, 1535-1541.

12. Schuster L, Rothmund L, He XL, Van Landuyt KL, Schweikl H, Hellwig E et al. (2015) Effect of Opalescence(R) bleaching gels on the elution of dental composite components. Dent Mater 31, 745-757.

13. Yoshii E (1997) Cytotoxic effects of acrylates and methacrylates: relationships of monomer structures and cytotoxicity. $\mathrm{J}$ Biomed Mater Res 37, 517-524.

14. Kleinsasser NH, Schmid K, Sassen AW, Harreus UA, Staudenmaier R, Folwaczny M et al. (2006) Cytotoxic and genotoxic effects of resin monomers in human salivary gland tissue and lymphocytes as assessed by the single cell microgel electrophoresis (Comet) assay. Biomaterials 27, 1762-1770.

15. Schweikl H, Spagnuolo G, Schmalz G (2006) Genetic and cellular toxicology of dental resin monomers. J Dent Res 85, 870-877.

16. Gul P, Miloglu FD, Akgul N (2014) HPLC Analysis of eluted monomers from dental composite using different immersion media. J Liq Chrom Relat Tech 37, 155-170.

17. Pelka M, Distler W, Petschelt A (1999) Elution parameters and HPLC-detection of single components from resin composite. Clin Oral Investig 3, 194-200.

18. Turker SB, Biskin T (2003) Effect of three bleaching agents on the surface properties of three different esthetic restorative materials. J Prosthet Dent 89, 466-473.

19. Silva MFD, Davies RM, Stewart B, DeVizio W, Tonholo J, da Silva JG et al. (2006) Effect of whitening gels on the surface roughness of restorative materials in situ. Dent Mater 22, 919-924.

20. Sasaki RT, Barbosa CM, Florio FM, Basting RT (2007) 
Enamel microhardness and shear bond strength after treatment with an $18 \%$ carbamide peroxide bleaching varnish. Am J Dent 20, 324-328.

21. Maia E, Baratieri LN, de Andrada MAC, Monteiro S, Vieira LCC (2008) The influence of two home-applied bleaching agents on enamel microhardness: an in situ study. J Dent 36, $2-7$.

22. Alshali RZ, Salim NA, Sung R, Satterthwaite JD, Silikas N (2015) Qualitative and quantitative characterization of monomers of uncured bulk-fill and conventional resin-composites using liquid chromatography/mass spectrometry. Dent Mater 31, 711-720.

23. Cebe MA, Cebe F, Cengiz MF, Cetin AR, Arpag OF, Ozturk B (2015) Elution of monomer from different bulk fill dental composite resins. Dent Mater 31, E141-149.

24. Polydorou O, Beiter J, Konig A, Hellwig E, Kummerer K (2009) Effect of bleaching on the elution of monomers from modern dental composite materials. Dent Mater 25, 254-260.

25. Geurtsen W (1998) Substances released from dental resin composites and glass ionomer cements. Eur J Oral Sci 106, 687-695.

26. Goldberg M (2008) In vitro and in vivo studies on the toxicity of dental resin components: a review. Clin Oral Invest 12, $1-8$.

27. Demirci M, Hiller KA, Bosl C, Galler K, Schmalz G, Schweikl $\mathrm{H}$ (2008) The induction of oxidative stress, cytotoxicity, and genotoxicity by dental adhesives. Dent Mater 24, 362-371.

28. Noda M, Wataha JC, Kaga M, Lockwood PE, Volkmann KR, Sano H (2002) Components of dentinal adhesives modulate heat shock protein 72 expression in heat-stressed THP-1 human monocytes at sublethal concentrations. J Dent Res 81, 265-269.

29. Lefeuvre M, Amjaad W, Goldberg M, Stanislawski L (2005) TEGDMA induces mitochondrial damage and oxidative stress in human gingival fibroblasts. Biomaterials 26, 5130 5137.

30. Noda M, Wataha JC, Lewis JB, Lockwood PE, Komatsu H, Sano $\mathrm{H}$ (2003) $\mathrm{Hg}^{2+}$ and $\mathrm{Ni}^{2+}$ alter induction of heat shock protein-72 in THP-1 human monocytes. J Biomed Mater Res A $67,240-245$.

31. Issa Y, Watts DC, Brunton PA, Waters CM, Duxbury AJ (2004) Resin composite monomers alter MTT and LDH activity of human gingival fibroblasts in vitro. Dent Mater 20, 12-20.

32. Reichl FX, Seiss M, Marquardt W, Kleinsasser N, Schweikl $\mathrm{H}$, Kehe K et al. (2008) Toxicity potentiation by $\mathrm{H} 2 \mathrm{O} 2$ with components of dental restorative materials on human oral cells. Arch Toxicol 82, 21-28.

33. Moharamzadeh K, Van Noort R, Brook IM, Scutt AM (2007) Cytotoxicity of resin monomers on human gingival fibroblasts and HaCaT keratinocytes. Dent Mater 23, 40-44.

34. Volk J, Engelmann J, Leyhausen G, Geurtsen W (2006) Effects of three resin monomers on the cellular glutathione concentration of cultured human gingival fibroblasts. Dent Mater 22, 499-505.

35. Volk J, Leyhausen G, Dogan S, Geurtsen W (2007) Additive effects of TEGDMA and hydrogenperoxide on the cellular glutathione content of human gingival fibroblasts. Dent Mater 23, 921-926.

36. Engelmann J, Janke V, Volk J, Leyhausen G, von Neuhoff N, Schlegelberger B et al. (2004) Effects of BisGMA on glutathione metabolism and apoptosis in human gingival fibroblasts in vitro. Biomaterials 25, 4573-4580.

37. Engelmann J, Volk J, Leyhausen G, Geurtsen W (2005) ROS formation and glutathione levels in human oral fibroblasts exposed to TEGDMA and camphorquinone. J Biomed Mater Res B Appl Biomater 75, 272-276.

38. Chao HH, Zhang XF, Chen B, Pan B, Zhang LJ, Li L et al. (2012) Bisphenol A exposure modifies methylation of imprinted genes in mouse oocytes via the estrogen receptor signaling pathway. Histochem Cell Biol 137, 249-259.

39. Kita K, Jin YH, Sun Z, Chen SP, Sumiya Y, Hongo T et al. (2009) Increase in the levels of chaperone proteins by exposure to beta-estradiol, bisphenol A and 4-methoxyphenol in human cells transfected with estrogen receptor alpha cDNA. Toxicol in Vitro 23, 728-735.

40. Cataldi A, Zara S, Rapino M, Patruno A, di Giacomo V (2013) Human gingival fibroblasts stress response to HEMA: a role for protein kinase C alpha. J Biomed Mater Res A 101, 378-384.

41. Spagnuolo G, D'Anto V, Valletta R, Strisciuglio C, Scbmalz G, Scbweikl H et al. (2008) Effect of 2-hydroxyethyl methacrylate on human pulp cell survival pathways ERK and AKT. J Endodont 34, 684-688. 